that the musing dean, like other medical deans, realises that the problems of medical schools cannot be solved by any internal measure. They may, indeed, be ultimately insoluble since the aims of medical schools and the societies which support them are often at variance.

The question of student numbers is specially important. I believe strongly that developed countries have an obligation to their own youngsters to provide them with opportunities to study medicine relative to the (unknown) medical needs of the country. This view is not that of many well intentioned persons and is politically suspect in a society with high immigration rates.

Our acknowledged duty to developing countries is to provide relevant graduate training for doctors who will return and practice in their homelands. Relevant graduate training does not usually mean instruction in inappropriate high technology methods of diagnosis and treatment.

It is immoral, though financially expedient, for developed countries with a high doctor to patient ratio to accept permanently doctors from countries with great medical need. This exacerbates their lack of facilities and in some instances has led to deliberate lowering of standards so that graduates are no longer acceptable or registrable in other parts of the world. The long term answer must be to encourage self help and cooperation and not to reap their scant medical harvests.

University of Western Australia

R A Joske

University of Western Australia
School of Medicine,
Queen Elizabeth II
Medical Centre,
Nedlands,
Western Australia 6009

Comparison of reliability of tests to distinguish upper from lower urinary tract infection

SIR,-It was disturbing to read the paper by Dr G H C Schardijn and others (4 August, p 284) claiming that scintiphotography with gallium-67 and measurement of urinary $\beta_{2}$ microglobulin are the two most reliable noninvasive methods to assess the site of an acute urinary tract infection.

Firstly, it was not surprising that all patients with acute pyelonephritis showed a positive scintiphotography test, as this was one of four diagnostic criteria of acute pyelonephritis used to select patients for the study. Secondly, in the introduction to their paper $\mathrm{Dr}$ Schardijn and others correctly point out that an intravenous pyelogram is of limited value in localising an acute renal infection. Nevertheless, they use radiological abnormalities of the upper urinary tract as another criterion of acute pyelonephritis. Thirdly, we are not told what clinical findings were typical of an acute renal infection. One might assume that many or all of these patients had a raised body temperature, particularly since they had positive blood cultures. Fourthly, we are not informed whether the patients with acute pyelonephritis were given aminoglycosides, substances known to interfere with proximal tubular function.

In our opinion increased excretion of $\beta_{2}$ microglobulin is a phenomenon associated with fever irrespective of its origin. In a recent study we investigated the urinary excretion of four markers of proximal tubular dysfunction in adult women with various forms of urinary tract infection and in fever due to non-renal infections. We found that the urinary concentrations of $\alpha_{1}$ microglobulin, $\beta$ microglobulin, retinol binding protein, and the lysosomal enzyme $\mathrm{N}$-acetyl- $\beta$ - $D$-glucose-aminidase were significantly increased in acute pyelonephritis compared with acute cystitis and asymptomatic bacteriuria. Patients with fever of non-renal origin, however, also had tubular proteinuria and enzymuria comparable to the concentrations in acute febrile pyelonephritis.

In contrast, we have noticed normal urinary excretion of tubular proteins in a few patients with impaired healing of acute pyelonephritis and persistent bacteriuria but with normalised temperature. There seems therefore to be a strong association between fever and proximal tubular dysfunction, which explains why tubular proteinuria is such a common finding in patients with acute pyelonephritis.

In general there should be no difficulty in differentiating between acute pyelonephritis and acute cystitis in adult women. Clinical judgment, including measurement of the body temperature and estimation of an acute phase reactant such as $\mathrm{C}$ reactive protein, should in most cases be sufficient to determine the site of an acute urinary tract infection. Tests for tubular proteinuria give no further information and should therefore be abandoned in the diagnosis of an acute urinary tract infection.

TORSTEN SANDBERG GuNILLA LidiN-JANSON

Department of Infectious

Diseases,

Ostra Hospital,

S-416 85 Göteborg,

Unit for Cancer Research,

University of Leeds,

Leeds

* *Dr Schardijn and Dr Statius van Eps reply below.-ED, $B M F$.

SIR,-Besides a raised temperature and costovertebral angle tenderness there are no typical clinical findings in acute pyelonephritis. Elderly or uraemic patients with urinary tract infection may have a positive blood culture despite normal or only slightly raised body temperatures.

In our study there was a significant correlation between the elevated gallium- 67 uptake in the kidney and tenderness of the renal region. All the urines for $\beta_{2}$ microglobulin determination were collected during the first days in hospital-before potential nephrotoxic agents could have been given. In a case of suspected pyelonephritis we start treatment with amoxicillin or cotrimoxazole. In our department aminoglycosides are not the first drug of choice.

We excluded patients who had been in shock or suffering from malignancies or preexistent tubular dysfunction. We disagree with Dr Sandberg and others that in adults only fever will cause an elevated urinary $\beta_{2}$ microglobulin excretion. We and other investigators have shown this in the past, ${ }^{12}$ and we did not observe increased $\beta_{2}$ microglobulin excretion in any patients with fever of non-renal origin (table).

Temperature and urinary excretion of $\beta_{2}$ microglobulin in 12 patients with fever of non-renal origin

\begin{tabular}{|c|c|c|c|c|}
\hline \multicolumn{2}{|c|}{ Patient } & \multirow{2}{*}{$\begin{array}{l}\text { Body temperature } \\
\left({ }^{\circ} \mathbf{C}\right)\end{array}$} & \multirow{2}{*}{$\begin{array}{l}\text { Urinary excretion of } \\
\beta_{2}-\text { microglobulin } \\
\text { ( } \mu \mathrm{g} / \text { day })\end{array}$} & \multirow{2}{*}{ Diagnosis } \\
\hline Age & Sex & & & \\
\hline $\begin{array}{l}78 \\
54 \\
27 \\
77 \\
63 \\
81 \\
32 \\
21 \\
40 \\
69 \\
21 \\
44\end{array}$ & $\begin{array}{l}M \\
M \\
\mathrm{~F} \\
\mathrm{~F} \\
\mathrm{~F} \\
\mathrm{~F} \\
\mathrm{~F} \\
\mathrm{M} \\
\mathrm{F} \\
\mathrm{F} \\
\mathrm{F} \\
\mathrm{M}\end{array}$ & $\begin{array}{l}39 \cdot 9 \\
39 \cdot 0 \\
38 \cdot 8 \\
39 \cdot 0 \\
40 \cdot 0 \\
38 \cdot 6 \\
40 \cdot 4 \\
39 \cdot 0 \\
39 \cdot 4 \\
38 \cdot 5 \\
38 \cdot 5 \\
38 \cdot 7\end{array}$ & $\begin{array}{r}198 \cdot 4 \\
138 \cdot 6 \\
60 \cdot 0 \\
135 \cdot 6 \\
284 \cdot 2 \\
88 \cdot 3 \\
146 \cdot 3 \\
256 \cdot 0 \\
194 \cdot 4 \\
218 \cdot 2 \\
74 \cdot 0 \\
70 \cdot 0\end{array}$ & $\begin{array}{l}\text { Fever of unknown origin } \\
\text { Endocarditis } \\
\text { Staphylococcal sepsis } \\
\text { Thrombosis cruris } \\
\text { Infection with Salmonella paratyphi } \\
\text { Herpes zoster } \\
\text { Systemic lupus erythematosus } \\
\text { Lobar pneumonia } \\
\text { Endocarditis } \\
\text { Gastroenteritis } \\
\text { Infection with Campylobacter jejuni } \\
\text { Pancreatitis }\end{array}$ \\
\hline
\end{tabular}

In our study the body temperatures of patients with upper urinary tract infection varied from $37 \cdot 6^{\circ} \mathrm{C}-40 \cdot 2^{\circ} \mathrm{C}$ and in those with lower urinary tract infection from $36.5^{\circ} \mathrm{C}$ $38.7^{\circ} \mathrm{C}$. In cases with raised urinary excretion of $\beta_{2}$ microglobulin and fever we advise a thorough search for kidney infection. We observed this in one patient with leptospirosis, one patient with cytomegalovirus infection (with a positive virus culture from the urine), and in several patients with staphylococcal sepsis (and negative urine cultures) with haematogenic renal abscesses.

$C$ reactive protein is not specific for renal infection-it is raised in all kinds of acute infectious diseases as well as in chronic inflammatory disorders. $\mathrm{C}$ reactive protein is more useful for measuring disease activity rather than for diagnosis. Interestingly, our results with urinary $\beta_{2}$ microglobulin excretion in urinary tract infection have been confirmed by others. $^{2} 3$

G H C SCHARDIJN

Stotervaart Hospital,
1066 EC Amsterdam,

1066 EC Amsterdam,

1 Schardijn GHC Statius van Zonneveld AAM, Kager JCGM, Persijn JP. Urinary $\beta_{2}$-microglobulin excretion in urinary tract

2 Schena FP, De Cesaris R, Tedesco A, La Raia E, Bonomo $L$. Urinary excretion of $\beta_{2}$-microglobulin and albumin during antibiotic therapy in urina

3 Sethi $\mathrm{T}$. 176.

Salivary oestriol to progesterone ratio in relation to spontaneous labour

SIR,-Mr Hugh H G McGarrigle and Dr Gillian C L Lachelin describe the progressive increase of the salivary oestriol to progesterone ratio in late pregnancy (25 August, p 457). We have found very similar results (figure). We strongly disagree, however, with their conclusion that these findings support any biological role for these hormones in the onset

Firstly, the production of both oestrogens and progesterone in pregnancy is the result of underlying processes which reflect the increasing maturity of the fetus and the placenta but which do not necessarily relate directly to the onset of labour. ${ }^{1-3}$ Thus, the rising concentrations of oestrogens during the last weeks of pregnancy reflect an increasing precursor supply from the fetal adrenal, while the plateau of progesterone concentrations reflects a comparable plateau in the functional mass of the placenta.

Secondly, showing an increasing oestriol to progesterone ratio in late pregnancy is not at L W Statius Van Eps infection by $\beta_{2}$-microglobulin. Kidney Int $1984 ; 25$ : of spontaneous labour in women. 
all original. " Indeed, this has been the conclusion of all previous studies, and that it is also observed in saliva can hardly be described as surprising.

Thirdly, the only way in which it would be possible to prove any direct relation between the oestriol to progesterone ratio and the initiation of labour would be to show that this

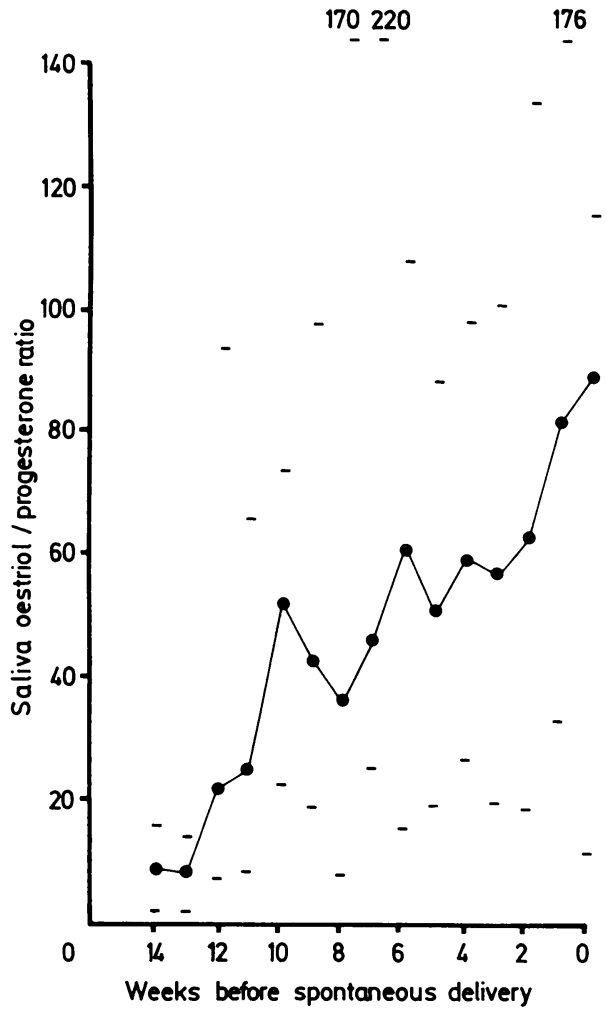

The relation between the saliva oestriol to progesterone ratio and the interval between sampling and spontaneous delivery is shown (median: solid line with 10 th and 90th centiles). Single specimens of saliva were collected from 184 clinically normal women at $28-42$ weeks of pregnancy. immunoassay.

ratio is related to the interval between the time of sampling and the time of the onset of labour for subjects at a given week of gestation. This evidence is not available in the study by Mr McGarrigle and Dr Lachelin, and we have evaluated it in relation to our own investigation with entirely negative results.

L Perry

N WATHEN

T CHARD

Departments of Obstetrics and
Gynaecology, and Reproductive Biology,

St Bartholomew's Hospital

Medical Cullege,

De Hertogh R, Thomas K, Bietlot Y, Vanderheyden I, Ferin J. Plasma levels of unconjugated oestrone, pregnancy in normal women. $f$ Clin Endocrinol pregnancy in normal
Metab $1975 ; 40: 93-101$

2 Mathur RS, Landgrebe S, Williamson HO. Progesterone, 17 alpha $\mathrm{OH}$ progesterone, oestradiol and oestriol in late pregnancy and labour. Amer $\mathcal{f}$ bstet Gynec 1980;136:25-7.

3 Tulchinsky D, Hobel CJ. Plasma human chorionic gonadotrophin, oestrone, oestradiol, progesterone and 17 alpha hydroxyprogesterone in human pregnancy. III. Early normal pret

4 Liggins GC, Fairclough RJ, Grieves SA, Kendall JZ, Knox BS. The mechanism of initiation of partu-
rition in the ewe. Re' Prog Horm Res 1973;29: rition in

5 Turnbull AC, Patten PT, Flint APF, Keirse MJNC, Jeremy JY, Anderson ABM. Significant fall in progesterone and rise in oestradiol levels in human peripheral plasma before onset of labour. Lancet $1974 ;$ i: $101-3$.
6 Kauppila A, Jouppila P, Karvonen P, Tuimala R, Ylikorkala $\mathrm{O}$. Effect of dexamethasone on blood levels of ACTH, cortisol, progesterone, oestradio and oestriol during late pregnancy. Int $f$ Gynaec Obstet 1976;14:177-81.

** Mr McGarrigle and Dr Lachelin reply below.-ED, $B M \mathcal{H}$.

SIR,-We did not claim that an increasing free oestriol to progesterone ratio is responsible for the initiation of spontaneous labour in women. We reported our findings and suggested that the changing ratio may be of importance.

We do not know how Mr Perry and others can evaluate the relation between the changing ratio and the onset of labour in individual women from single specimens.

They state that showing an increasing oestriol to progesterone ratio in late pregnancy is not at all original, but the oestriol to progesterone ratio is not even mentioned in any of the references which they cite. Their reference 4 relates to the ewe, and their reference 5 is concerned with plasma unconjugated oestradiol to progesterone ratios in pregnant women. Oestriol concentrations were not measured in either study. Their reference 6 relates to the effect of dexamethasone on various steroid concentrations, but ratios are not described or discussed. Two important studies in which a change in the plasma unconjugated oestriol to progesterone ratio in late pregnancy was specifically looked for failed to find any such change. ${ }^{12}$

Our study was designed to examine free (unbound unconjugated) steroid concentrations, which are very different from the plasma unconjugated (bound and free) concentrations previously described. The free (biologically available) concentrations are likely to be of more physiological importance. Saliva (free) oestriol concentrations in late pregnancy are 15 times higher than saliva oestradiol concentrations, whereas plasma unconjugated oestriol concentrations are lower than plasma unconjugated oestradiol concentrations. Saliva oestriol and progesterone concentrations are similar in late pregnancy, whereas plasma unconjugated oestriol concentrations are approximately one tenth of plasma progesterone concentrations. Thus, our findings are both qualitatively and quantitatively different from previously reported measurements of oestrogens and progesterone in pregnancy.

As to the biological implications of ou findings, it has recently been shown in vitro that the positive cooperative equilibrium binding of oestradiol with calf uterine oestrogen receptors is inhibited by oestriol, with oestrio concentrations twofold above oestradiol concentrations reducing the receptor cooperativity by $50 \%$ of its maximum value. ${ }^{3}$ One can speculate that the progesterone block is maintained during pregnancy by the unchanging oestradiol to progesterone ratio acting on nuclear receptors in the myometrium. Then the slowly rising oestriol concentrations competing with oestradiol for occupancy of the oestrogen receptors disrupt the oestradiol to progesterone balance, allowing oestriol increasingly to regulate (via gene expression) the synthesis of those proteins involved in gap junction and oxytocin receptor formation and also to influence the production and release of prostaglandins.

Hugh H G McGarRIGLE

Department of Obstetric Gili.ian C L L,ACHELIN

and Gynaecology,

University College,
London WC, $6 \mathrm{HX}$
Tulchinsky D, Hobel CJ, Yeager E, Marshall JR. Plasma estrone, estradiol, estriol, progesterone and 17 hydroxyprogesterone in human pregnancy. $\mathrm{Am} \mathcal{F}$ Obstet Gynecol 1972;112:1095-100

2 Shaaban MM, Klopper A. Changes in unconjugated oestrogens and progesterone concentrations in plasma at the approach to labour. F Obstet Gynaecol Brit Comm 1973;80:210-7.

3 Sasson S, Notides AC. Estriol and estrone interaction with the estrogen receptor. II Estriol and estrone ${ }^{3}[\mathrm{H}]$ estradiol to the estrogen receptor. 7 Biol Chem 1983;258:8118-22.

\section{Different types of neurologist}

SIR,-Dr Anthony Hopkins's paper on different types of neurologist (9 June, $p$ 1733) deserves thoughtful consideration and, I believe, action not only by neurologists but also by those concerned for the general provision of medical services. In brief, he argues that neurology has become increasingly isolated from general medicine. He also expresses anxieties about the "reluctance of many neurologists to be involved in research."

I write with the experience of neurology in two centres in the United Kingdom (Oxford and Glasgow), and of neurological practice in North America as a visiting professor, and from my present experience in New Zealand. Each of the centres I have known has had strengths stemming from the staff which run counter to the approach described by Dr Hopkins. For example, in Oxford the respiration unit in the department of neurology pioneered the treatment of acute neurological diseases with respiratory problems. In Glasgow the particular interest of the professor of neurology meant that certain neurological diseases were managed in the acute phases. In all centres research was a strong component.

The present sophistication of British neurology would be dissipated by trying to alter neurological training to that which would be required to produce physicians with a special interest in neurology. Instead there needs to be a much more specific statement on the role of specialties such as neurology. Appointment conditions should state specifically that a consultant is responsible for taking part in the total management of the clinical problems related to his discipline within his regional board's area. Such a statement would mean that each specialist group would have to consider the proper organisational facilities within the region, putting the needs of the patients first rather than the historical relation of the discipline to one centre. This should then mean that specialists would be responsible for both acute management and rehabilitation. For example, the management of stroke and of paraplegia would require consideration, and there would have to be discussion with other specialist groups over the services provided. Giving responsibility to the specialist group for particular diseases such as stroke would prevent the present ad hoc development of services which largely depend on the historical developments in each region. It would also mean an increase in practical neurological services.

If neurology was seen to be more concerned with the full range of neurological diseases then there would be much greater pressure on the teaching hospitals and medical schools to develop academic units in neurology. Such departments would not only be concerned with diagnosing uncommon disorders but would admit acute neurological problems and use this as a base for providing consultative services and rehabilitation. The failure of 